\title{
Rufaidah Al-Aslamiyah: Perawat Pertama di Dunia Islam (Abad 6-7 M.)
}

\author{
Abdul Hamid Saputra, Ading Kusdiana, Tolib Rahmatillah \\ Fakultas Adab dan Humaniora, Universitas Islam Negeri Sunan Gunung \\ Djati Bandung \\ Email: saputraah05@gmail.com
}

\begin{abstract}
The practice of Islamic health emerged in the sixth century $A D$ influenced by three health traditions, namely ancient civilization, Bedouin Arabic, and Thibbun Nabawi. There is no much data related to health practice around the sixth century to the seventh century $B C$, except for nursing conducted by Rufaidah Al-Aslamiyah. She became an important figure in developing Islamic health practice and the involvement of women in the Islamic war. The purpose of this research is to determine the description of medicine/health in the Islamic world in the classical period and the role of Rufaidah Al-Aslamiyah in her involvement nursing field of the Islamic world. The method of this research is the historical research. The research method was carried out through four-stage, they are heuristics, criticism, interpretation, and historiography. Based on the research conducted, it could be stated that the practice of world health has emerged since 7,000 BC. In the sixth to seventh centuries Rufaidah Al-Aslamiyah had an important role in the development of world health practice. She started nursing for the first time in the Islamic world. Some of her important roles include: establishing a nursing school, participating in the war, establishing a field hospital, creating a nurse code of ethics, developing Islamic spiritual services, and being active in social activities in the city of Medina. It has also been proven that the first nursing knowledge was not conceived by Florence Nightingale in the 19th century, however, it has existed since the sixth century by Rufaidah Al-Aslamiyah.
\end{abstract}

Keywords: Health practice, Islamic health practice, nursing. 
Rufaidah Al-Aslamiyah: Perawat Pertama di Dunia Islam (Abad 6-7 M.) $\mid$ Abdul

Hamid Saputra, dkk

\section{Pendahuluan}

Praktik-praktik kesehatan Islam pada abad keenam sampai abad ketujuh merupakan gabungan antara pelayanan kesehatan kuratif (curative health care) dan pelayanan pencegahan atau preventif (preventive health care). ${ }^{1}$ Praktik kesehatan Islam masa awal ini juga tidak membedakan antara perawat dan dokter, karena fakta-fakta telah menunjukan bahwa hampir seluruh proses itu dilakukan oleh perawat sekaligus dokter. Maka, istilah atau sebutan khusus dan klasifikasi perawat maupun dokter tidak dikenal pada masa ini.

Kesehatan Islam ini sejak awal dipengaruhi oleh dua tradisi kesehatan dari peradaban sebelumnya, yakni Barat dan Timur. Tradisi Barat ini mewariskan dasar-dasar pengobatan yang dipelopori oleh Hippocrates. ${ }^{2}$ Prinsip dasar dari teknik kesehatan Barat mengedepankan pentingnya diet, gaya hidup, dan memprediksi evolusi penyakit yang kemudian hampir semua diambil dari catatan-catatan risalah Hippocrates yang menekankan pada ekologis. ${ }^{3}$ Sedangkan tradisi Timur mewariskan metode bedah yang dikembangkan sangat baik dengan penggunaan afium (opium) sebagai anestesi (pembiusan). Selain teknik bedah, tradisi Persia juga memperkenalkan alat-alat kedokteran dari bahan logam. Ditambah lagi perkembangan sekolah kedokteran dengan kurikulum yang sudah terstruktur di Persia sebelumnya mewariskan sistem rumah sakit. ${ }^{4}$

Ketika Islam tumbuh pada abad ketujuh, tradisi kesehatan Yunani dan Persia tetap hidup melalui para dukun atau tabib yang mendominasi praktikpraktik kesehatan yang masih digunakan sampai pada masa Islam. Sebagai contoh Ibn Usaibah menyatakan dalam karyanya yang berjudul Tabaqat alAtba' (Peringkat para Tabib) bahwa tabib bangsa Arab yang bernama alHaris ibn Kaladah yang memeluk Islam pada masa tuanya adalah alumnus sekolah kedokteran di Jundisapur dan dia memperoleh tempat tersendiri dalam disiplin ilmu kedokteran. Bahkan Kaisar Anusyirman mengakui kepakaran al-Haris ibn Kaladah ketika dia menyembuhkan sakitnya. ${ }^{5}$

${ }^{1}$ Tri Niswati, Perspektif Kesehatan Masyarakat Teori Dan Aplikasi (Yogyakarta: Deepublish, 2012). 3

2 Maryam, "Perkembangan Kedokteran Dalam Islam," Sulesana 6, no. 2 (2011). 80

${ }^{3}$ Chairuddin P. Lubis, "Sejarah Ilmu Kedokteran,” Usu e-Repository, 2008. 3

${ }^{4}$ Hikmatul Aminah, "Sejarah Kedokteran Masa Kemunduran Dinasti Abbasiyah (447-656 H/ 1055-1258 M)" (UIN Sunan Ampel Surabaya, 2016). 13

5 Ahmad Syauqi, Rufaidah: Kisah Perawat Wanita Pertama Dalam Sejarah Islam (Yogyakarta: Navila, 2010). x 
Kebutuhan akan peran ahli kesehatan lebih tinggi ketika terjadi peperangan yang dilakukan umat Islam. Pada periode ini, Nabi dan umat Islam melakukan sejumlah peperangan. Setidaknya riwayat dari Sahih AlBukhari peperangan yang diikuti langsung oleh Rasulullah saw berjumlah enam belas kali. Sementara dari riwayat Muslim menyebutkan Rasulullah saw berperang sembilan belas kali. Sumber lain mengatakan bahwa peperangan yang terjadi pada periode kenabian berjumlah 27 kali. $^{6}$

Peperangan tersebut menimbulkan banyak korban jiwa dan cacat fisik maupun mental. Mereka ada yang terluka karena kibasan pedang, tertusuk tombak, dan dihujani oleh anak panah musuh. Sebagian besar prajurit mengalami perdarahan yang sangat hebat. Mereka yang menjadi korban dibawa kemudian dirawat ditempat yang sudah ditentukan. Bahkan pada peristiwa perang khandaq masjid Nabawi berubah menjadi tempat merawat korban perang. ${ }^{7}$

Sebagian besar dari para perawat itu adalah wanita. Mereka berada di kisaran kelompok umur 20 - 45 tahun yang terdiri dari istri, putri, dan sahabat perempuan Nabi Saw. Peran mereka saat itu merawat para prajurit dari garis pertempuran paling belakang. Keterlibatan mereka ini atas dasar inisiatif yang tinggi dan telah mendapatkan izin dari Rasulullah Saw. ${ }^{8}$

Tugas mereka dalam merawat korban perang itu terkait beberapa hal. Pertama, mereka mengkarantina orang yang menderita sakit dan yang terluka serta menyuplai air pada para prajurit yang kehausan dalam perang. Kedua, mereka mengangkut orang-orang yang terluka dan yang mati syahid dalam perang tersebut. Ketiga, mereka membantu para prajurit memanggul mesin senjata, membawakan panah, dan fasilitas perang lainnya. ${ }^{9}$

Salah satu dari orang yang dikenal sebagai perawat awal Islam adalah Rufaidah. Ia adalah anak seorang tabib yang berasal dari Bani Aslam yang mengobati orang-orang yang terluka ketika peperangan terjadi antara umat

\footnotetext{
${ }^{6}$ Ibnu Katsir, Ringkasan Bidayah Wa Nihayah: Sejarah Awal Mula Penciptaan, Kisah Para Nabi, Kisah Umat-Umat Terdahulu, Sejarah Nabi Saw Dan Khulafa' Rasyidun, Daulah Usmaniyah Dan Abasiyah, Hingga Peristiwa Tahun 768 H, ed. Dr. Ahmad AlKhani (Riyadh: Arsyad Maghal, 1424). 171

7 Muhammad Ibrahim Salim, Nisa'a Haula Ar-Raasuul (Sudan: Maktabah Ibnu Sina, 1990). 161

${ }^{8}$ Mohammad Altaf, "Great Woman of Islam (Rufaidah Bint Sa'ad)," Heart Beat, no.

http://tabbaheart.org/wpcontent/themes/panoramic/library/images/newsletters/Issue 02.pdf.

${ }^{9}$ Taufik Munir, "Peran Aktif Perempuan Muslim," Muwazah 6, no. 1 (2014). 121
} 
Islam dan kaum kafir Quraisy. ${ }^{10}$ Bani Aslam ini sangat terkenal dengan kehebatan mereka dalam mengobati orang yang sakit sejak zaman pra-Islam.

Rufaidah terkenal di kalangan masyarakat pada saat itu karena dua hal. Pertama, kala itu ia dikenal sebagai pakar pengobatan dan ilmu bedah. Ia biasa mengkarantina orang-orang yang sakit dan terluka di medan pertempuran. ${ }^{11}$ Bahkan dalam perang khandaq ia mengusulkan diri kepada rasulullah saw untuk ikut andil dalam perang tersebut. ${ }^{12}$ Kedua, Ketika masa damai beliau mendirikan tenda kesehatan di depan masjid Nabawi. Kemudian perhatiannya tidak terbatas di tenda kesehatan saja, dia mencoba mengatasi masalah sosial yang akan menyebabkan penyakit. Selain itu, membantu setiap muslim yang membutuhkan, memelihara yatim piatu, dan mendidik mereka. ${ }^{13}$

Dalam menyusun kajian kali ini penulis memerlukan batasan-batasan dalam melakukan penulisan. Pada batasan temporal kajian ini ditentukan dari masa hidup Rufaidah hingga wafatnya beliau, yakni sekitar abad keenam sampai dengan abad ketujuh masehi yang sezaman dengan Rasulullah Saw. Batasan spasial kajian ini meliputi peranan dia sebelum masuknya Islam ke Madinah dan peranan dia dalam perang-perang tertentu, terutama setelah Nabi Muhammad Saw hijrah ke Madinah.

\section{Metode Penelitian}

Metode penelitian kajian ini menggunakan metode penelitian sejarah. Metode ini bertujuan menemukan sebuah evaluasi sistematis dan objektif serta sintesis bukti-bukti untuk menghadirkan fakta dan menarik kesimpulan mengenai kejadian-kejadian lampau. $^{14}$ Dalam penelitian ini, penulis menggunakan katalog-katalog sebagai alat utama dalam melakukan heuristik. Penulis mengambil langkah awal dengan cara membaca bibliografi terdahulu yang berkaitan dengan topik penelitian. Hasil dari bacaan ini penulis mendapatkan sebagian data, kemudian mencatat sumber-sumber terkait yang dipergunakan dalam karya terdahulu itu. Penulis mulai dapat

${ }^{10}$ Umma Farida, 25 Perempuan Teladan(Para Istri, Putri, \& Sahabat Perempuan Nabi Saw.) (Kudus: STAIN Kudus, 2012). Bagian 22

${ }^{11}$ Munir, "Peran Aktif Perempuan Muslim." 121

${ }^{12}$ Syauqi, Rufaidah: Kisah Perawat Wanita Pertama Dalam Sejarah Islam. vii

${ }^{13}$ Uswatun Khasanah, "Rufaida Al-Asalmiya: Florence Nightingale Muslim Di Dunia Islam," Mutiara Medika 6, no. 1 (2006). 74

${ }^{14}$ Nicholas Walliman, Research Methods: The Basics (New York: Routledge, 2011). 9 
menjaring jejak-jejak sejarah yang ditemukan dan mengklasifikasikan sumber sejarah yang tepat atau tidak. ${ }^{15}$ Selanjutnya, untuk menelusuri data yang ada dan melakukan pendalaman kajian penulis mengunjungi berbagai perpustakaan, diantaranya: perpustakaan fakultas Adab dan Humaniora, perpustakaan UIN Sunan Gunung Djati Bandung, perpustakaan pribadi teman-teman seperjuangan, Badan Perpustakaan Daerah Jawa Barat (BAPUSIPDA), dan Perpustakaan Nasional (PERPUSNAS). Selain itu, penulis juga mengunjungi situs terpercaya di jejaring internet dalam mendapatkan sumber, seperti: oapen.org, arvhieve.org, guetenberg.org, waqfeya.com, freefullpdf.com, reseachgate.org, delpher.nl, portalgaruda.com, pdfdrive.net, gen.lib.rus.ec dll.

Penelitian ini mengikuti Great Men sebagai mazhab. Penelitian ini akan menjelaskan bagaimana peran tokoh Rufaidah terhadap dunia keperawatan Islam juga didekati secara teori Great Men. Lebih jauh lagi penjelasan mengenai Rufaidah itu tidak hanya dijelaskan bagaimana Rufaidah dan seluruh pengaruhnya terhadap dunia kesehatan tetapi juga mengaitkannya dengan dunia sosial yang ada pada masyarakat saat itu. Penelitian ini juga menggabungkan apa yang dilakukan Hendry Sigerist yang menyatukan sejarah kesehatan dengan sosialnya yang dia sebut sebagai sejarah sosial kesehatan. Dalam teori seperti ini akan dilihat bagaimana institusi kedokteran, dokter dan karakternya, sejarah pasien dalam masyarakat, dan sejarah hubungan antara dokter dan pasien. ${ }^{16}$ Jika kita hubungkan dengan Rufaidah sebagai tokoh perawat pertama di dunia Islam sangat jelas mendekati. Pertama, ada kemungkinan dia membuat institusi perawat sebelum maupun setelah peperangan bersama rasulullah Saw. karena ketika dia hendak pergi ke medan pertempuran dia mengajarkan ilmu keperawatan kepada istri, anak, dan para sahabat wanita rasulullah Saw. Kedua, Rufaidah memiliki karakter layaknya sikap perawat profesional saat ini yang memiliki keterlibatan, respek, empati, dan kesungguhan. ${ }^{17}$ Ketiga, Rufaidah dapat mendedikasikan hidupnya untuk kemanusiaan. Ketika perang dia akan maju ke medan perang untuk membantu para mujahid yang terluka.

\footnotetext{
${ }^{15}$ Dudung Abdurahman, Metode Penelitian Sejarah (Jakarta: Logos, 1999). 55

${ }^{16}$ Charles R. King, "The Historiography Of Medical History: From Great Men To Archaelogy," Buletin of The New York Academy of Medice 67, no. 5 (1991). 417

${ }^{17}$ Khairiah, "Faktor-Faktor Yang Berhubungan Dengan Kepatuhan Perawat Untuk Menggunakan Alat Pelindung Diri Di Rumah Sakit Islam Faisal Makassar" (UIN Alauiddin Makassar, 2012). 18
} 
Sebagaimana dalam penelitian ini dia akan digambarkan menolong Saad bin Muadz yang terluka karena sebuah peperangan. Selain itu, ketika tidak terjadi peperangan dia membuat tenda kesehatan dekat masjd Nabi serta memelihara anak yatim selama sisa hidupnya.

Maka dari itu, penelitian ini dapat dipahami bukan sebagai narasi tokoh tetapi juga menjelaskan tokoh dan konteks sosialnya. Dari kedua pendekatan itu maka Rufaidah akan dijelaskan sebagai seorang tokoh yang berpengaruh dalam dunia Islam, kesehatan Islam, peperangan, dan di kota madinah. Akan tetapi, pengaruhnya itu dijelaskan melalui peran dia dan latar tempat yang berpengaruh timbal balik antara Rufaidah dan masyarakat.

\section{Hasil dan Pembahasan}

\section{Biografi Rufaidah Al-Aslamiyah}

Biografi Rufaidah terdapat hal yang cukup jelas dan ada pula yang kurang jelas. Bisa dipastikan ia hidup kurang lebih pada masa sebelum dan sesudah Islam masuk ke Madinah. ${ }^{18}$ Ia lahir di Yathrib, sekitar 25 tahun sebelum kedatangan Rasulullah Saw. Jika pendapat ulama ini benar, maka ia lahir sekitar tahun $597 \mathrm{M}$.

Kitab-kitab sejarah telah mencatatnya dengan nama yang berbedabeda. Tetapi semuanya merujuk kepada ia seorang. Sumber pertama menyebutkan namanya adalah Rufaidah binti Sa'ad Al-Bani Aslam AlKharaj. ${ }^{19}$ Sumber kedua menyebutkan nama Ku'aibah binti Sa'ad. ${ }^{20}$ Sumber ketiga ia sering disebut Rumaitsah Al-Ansariyah. ${ }^{21}$ Namun dari data yang ada, nama yang umum dikenal adalah Rufaidah.

Jika melihat data di atas, ia termasuk ke dalam marga Aslam. Marga ini adalah salah satu marga dari suku Khazraj di Madinah. Ia juga termasuk ke dalam kaum Ansar, yakni golongan yang pertama kali menganut Islam di Madinah. ${ }^{22}$ Jika demikian ia dianggap sebagai mukhadram, sebuah kondisi dimana seseorang mengalami masa jahiliah dan masa Islam dalam sekaligus. $^{23}$

${ }^{18}$ Syauqi, Rufaidah: Kisah Perawat Wanita Pertama Dalam Sejarah Islam. ix

${ }^{19}$ Syauqi. vi

${ }^{20}$ Imam Al-Wakidi, Kitab Al-Maghazi (Alamul Kutub, 1404). 565

21 Aba Naim Al-Asfahani, Ma'rifah Ash-Shahabiyah (Riyadh: Darul Wathan, 1419). 3334

22 Andi Aswin Dahlan, "Profesi Perawat Dalam Perspektif Islam," 2014, id.scribd.com.

${ }^{23}$ Syauqi, Rufaidah: Kisah Perawat Wanita Pertama Dalam Sejarah Islam. ix 
Ia berasal dari kalangan para tabib. Ia memiliki seorang Ayah yang bernama Sa'ad Al-Aslami. Ayahnya adalah seorang tabib terkemuka, bahkan seorang pimpinan atau imam para tabib di kalangan masyarakat kota Madinah. Ayahnya juga dikenal memiliki kemampuan pengobatan yang terkenal di seluruh jazirah Arab. Bahkan, masyarakatnya mengklaim bahwa ayahnya dapat menjadi perantara dalam menyembuhkan penyakit melalui doa-doa dan jimat yang ia miliki. Penjelasan terkait keluarga Rufaidah tidak diungkap lebih jauh dalam kitab-kitab. Penjelasan tentang ibu, saudara, suami, dan anaknya tidak diketahui. ${ }^{24}$

Terkait pendidikan keperawatan yang diterimanya, didapat dari ayahnya yang berprofesi sebagai tabib. ${ }^{25}$ Praktik keperawatan sudah melekat di kehidupannya dan telah dimulai sejak masih kecil. Ketika sudah menginjak usia remaja, ayahnya meminta ia bekerja sebagai asisten ayahnya. ${ }^{26}$ Hingga usia dewasa, ayahnya memberikan kepercayaan kepadanya untuk mengembangkan kemampuannya dalam merawat. Pengawasan sudah jarang dilakukan lagi oleh ayahnya ketika ia sedang merawat pasien. Ayahnya telah mewariskan praktik keperawatan dasar masyarakat Arab dan kemudian dikembangkan ketika periode Islam di Madinah.

Ketika Islam masuk ke Madinah pada abad ketujuh ia telah menjadi mukhalaf dan berhasil menggabungkan keilmuannya dalam bidang keperawatan dengan ajaran Islam. Kemudian berkontribusi terhadap kesehatan umat Islam di Madinah. Pada masa peperangan telah ikut serta ke medan perang untuk menangani orang yang terluka dan ketika damai ikut andil dalam aktivitas sosial di masyarakat kota Madinah. Akhir hayatnya tidak ada kepastian, akan tetapi satu yang pasti bahwa ia tidak pernah pindah ke tempat manapun. Maka, dapat dipastikan bahwa meninggalnya di kota kelahirannya Madinah.

\section{Peranan Rufaidah Al-Aslamiyah dalam Ilmu Keperawatan sebelum Islam masuk ke Madinah}

\footnotetext{
${ }^{24}$ Sandra Lovering, “Arab Muslim Nurses' Experiences of The Meaning of Caring” (The University of Sydney, 2018). 98

${ }^{25}$ Heri Ruslan, "Rufaidah Al-Anshariyah Perintis Dunia Keperawatan Islam," Tabloid Republika (Jakarta, 2010). 21 Islam." 75

${ }^{26}$ Khasanah, "Rufaida Al-Asalmiya: Florence Nightingale Muslim Di Dunia
} 
Rufaidah Al-Aslamiyah mengalami kehidupan jahiliah dan masa Islam sekaligus. ${ }^{27} \mathrm{Hal}$ ini berpengaruh terhadap peranannya di masyarakat. Kontribusi ia di kota Madinah adalah mengembangkan praktik keperawatan tradisi lokal warisan ayahnya dengan tradisi Islam. Pada kajian kali ini akan melihat peranannya pada masa jahiliah.

Kondisi praktik kesehatan di masa Rufaidah dan ayahnya hidup dipengaruhi oleh praktik kesehatan Persia dan Byzantium. ${ }^{28}$ Hal ini dikarenakan sekitar abad keenam penduduk Arab berada dalam kurun waktu kedua kerajaan ini. Praktik kesehatan yang diserap oleh Rufaidah dari ayahnya kala itu terkait praktik keperawatan. Mereka mengenal dua tradisi praktik kesehatan selama masa jahiliah yakni, praktik kesehatan lokal masyarakat Arab dan praktik kesehatan peradaban kuno.

Praktik kesehatan lokal masyarakat Arab terbilang masih sederhana sesuai keadaan geografis. Mereka memanfaatkan kondisi alam untuk melakukan praktik kesehatan. Mereka sebagian besar bergantung kepada hewan dan tumbuhan yang ada di sekitar mereka seperti: jinten hitam, bunga Memecylon, truffle gurun, air kencing unta, empedu hewan buas, susu keledai betina, dan lemak cair dari ekor domba. ${ }^{29}$ Selain itu, mereka telah mengembangkan teknik pengobatan seperti: teknik venesection, kauterisasi, dan bekam. ${ }^{30}$ Teknik venesection adalah teknik pengobatan yang dilakukan dengan cara mengeluarkan darah dari pembuluh darah vena. Teknik ini dilakukan ketika pasien mengalami sumbatan-sumbatan tertentu di daerah pembuluh darah vena akibat dari pola makan yang tidak teratur. Selanjutnya, teknik kauterisasi. Teknik ini dilakukan dengan cara menyulut badan dengan besi yang telah dipanaskan. Teknik ini dilakukan untuk mengatasi penyakit mental, kudis, keropeng, dan luka terbuka lainnya. ${ }^{31}$ Terakhir adalah teknik bekam. Teknik ini merupakan teknik pengobatan yang dilakukan dengan cara menyedot keluar darah kotor yang ada di tubuh. Teknik ini dipercaya mampu mengeluarkan racun dan zat berbahaya dalam tubuh.

\footnotetext{
Press, 2008). 71

${ }^{29}$ Muhammad Iqbal Syauqi, "Sisi Lain Thibbun Nabawi: Nabi Tidak Mengubah Tradisi Pengobatan Bangsa Arab,” Islami, n.d., islami.co.

${ }^{30}$ Mark, A Global Histoty of Medicine. 70

${ }^{31}$ Syauqi, "Sisi Lain Thibbun Nabawi: Nabi Tidak Mengubah Tradisi Pengobatan Bangsa Arab."
}

${ }^{27}$ Syauqi, Rufaidah: Kisah Perawat Wanita Pertama Dalam Sejarah Islam. 9

${ }^{28}$ Jackson Mark, A Global Histoty of Medicine (New York: Oxford University 
Teknik-teknik pengobatan ini bukan praktik kesehatan bangsa Arab murni. Teknik-teknik ini merupakan warisan praktik kesehatan sebelumnya yang diselamatkan oleh bangsa Persia dan Byzantium yang kemudian berasimilasi dengan praktik kesehatan lokal bangsa Arab. Teknik pengobatan venesection dan kauterisasi berasal dari praktik kesehatan Yunani kuno. Praktik kesehatan ini kemudian diselamatkan oleh Galen dan bertahan di Byzantium. Ketika Byzantium mengalami keruntuhan, teknik ini kemudian diselamatkan oleh bangsa Arab dan mengalami perkembangan. ${ }^{32}$ Sama halnya dengan teknik sebelumnya, teknik pengobatan bekam merupakan warisan praktik kesehatan dari Cina yang dikembangkan oleh bangsa Persia. ${ }^{33}$ Maka dari itu, kondisi praktik kesehatan saat itu terikat oleh tradisi lokal masyarakat Arab yang mereka ciptakan berdasarkan turun temurun dan dipengaruhi oleh praktik kesehatan dari luar yang berasal dari Persia dan Byzantium.

Praktik kesehatan yang masih sederhana di kalangan masyarakat Arab dianggap sebagai cerminan kondisi kehidupan masyarakat Arab sesuai tahapan sejarah mereka pada masa itu. ${ }^{34}$ Data dari para sejarawan Arab pun kebanyakan berkonsentrasi pada keyakinan dan segala sesuatu yang berkaitan dengan kepercayaan orang Arab pada masa jahiliah sampai datangnya agama Islam. Sehingga aktifitas para tabib atau dokter pada masa itu tidak menjadi perhatian mereka. Maka dari itu, data terkait peranan Rufaidah pada masa jahiliah tidak lebih dari beberapa halaman saja. ${ }^{35}$

Data yang ada terkait peranan ia pada masa jahiliah adalah menjadi asisten ayahnya dalam menolong orang. ${ }^{36}$ Tugasnya saat itu mengkondisikan pasien sebelum mendapatkan penanganan dari ayahnya. Tetapi, sesekali melakukan penanganan kepada pasien apabila keadaan darurat dan ketika ayahnya sedang tidak ada. Keahliannya lebih berkembang ketika memperhatikan ayahnya yang sedang merawat pasien dan lebih meningkat lagi ketika diberikan tanggungjawab oleh ayahnya dalam merawat, sehingga menjadi terlatih, mandiri, cekatan, dan ulet dalam melakukan setiap

${ }^{32}$ Yavor Mendel, Pengobatan Kuno (Cambridge: Cambridge Satnfords Books, 2019). 11

${ }^{33}$ Briliantono, Allah Sang Tabib: Kesaksian Seorang Dokter Ahli Bedah (Jakarta: AMP Press, 2010). 72

${ }^{34}$ Syauqi, Rufaidah: Kisah Perawat Wanita Pertama Dalam Sejarah Islam. ix

35 Syauqi. $\mathrm{x}$

${ }^{36}$ Altaf, "Great Woman of Islam (Rufaidah Bint Sa'ad)." 
perawatan. Pengobatan dan perawatan ini bersifat mistis dan sangat primitif yang diwariskan secara turun temurun.

Selain pengetahuan dari bangsa Arab asli ayahnya juga mengenalkan tradisi praktik kesehatan bangsa lain yang berasal dari wilayah Persia, Romawi, Siria dan India. Pengetahuan ini didapat melalui relasi perdagangan bangsa Arab dengan bangsa lain. Ketika mereka pulang ke kampung halaman, mereka mempraktikkan pengetahuannya kepada masyarakat. ${ }^{37}$ Jika kita melihat beberapa literatur sejarah praktik Islam. Isinya membahas tentang pengobatan pada abad ketujuh masehi, sejarah jahiliah, peranan filsuf dan penyair Arab dalam pengobatan, serta ajaran Islam dan pengaruhnya terhadap aktifitas pengobatan di semenanjung Arab. Hasil dari sintesis itu menghasilkan sebuah fakta bahwa pengobatan bangsa Arab tidak berbeda dengan ilmu-ilmu sekarang yang merupakan gabungan dari pengobatan tradisi lokal dengan pengobatan dari bangsa lain.

\section{Rufaidah Al-Aslamiyah dalam Ilmu Keperawatan sebelum Islam masuk ke Madinah}

Rufaidah Al-Aslamiyah telah dikisahkan sebagai dokter Perempuan Pertama dalam Islam oleh Umma Farida dalam karyanya yang berjudul 25 Perempuan Teladan (Para Istri, Putri, \& Sahabat Perempuan Nabi Saw.) ${ }^{38}$ Hal ini merujuk kepada pembagian kerja antara perawat dengan dokter pada abad ketujuh tidak begitu dijabarkan. Keduanya menjadi bias karena hampir melakukan hal yang sama. Akan tetapi, kisah Rufaidah yang berkaitan dengan perawat sangat mendominasi. Hal ini dijelaskan bahwa ia menjadi asisten selama ayahnya masih hidup dan belajar mengenai keperawatan dari ayahnya. ${ }^{39}$ Jika kita lihat peranan ia dengan konteks hari ini, peranan ia lebih mendekati kepada praktik keperawatan. Kajian kali ini akan melihat peranan Rufaidah Al-Aslamiyah setelah Islam masuk ke Madinah.

Islam masuk ke Madinah sekitar tahun $622 \mathrm{M} / 1 \mathrm{H}$, tepatnya pada 12 Rabiul awal tahun ke 13 kenabian. Kabar mengenai adanya ajaran Islam sudah lama terdengar oleh masyarakat Madinah. Dikisahkan oleh Ahmad Syauqi Al-Fanjuri bahwa Rufaidah sudah mengetahui adanya seorang rasul yang membawa risalah baru dari Mekah yang membawa perubahan bagi para

\footnotetext{
${ }^{37}$ Syauqi, Rufaidah: Kisah Perawat Wanita Pertama Dalam Sejarah Islam. x

${ }^{38}$ Farida, 25 Perempuan Teladan(Para Istri, Putri, \& Sahabat Perempuan Nabi Saw.). bagian 22

${ }^{39}$ Khasanah, "Rufaida Al-Asalmiya: Florence Nightingale Muslim Di Dunia Islam.” 75
} 
pemeluk-pemeluknya, terutama ajakannya untuk meninggalkan yang batil dan mengajak manusia kepada kebajikan. ${ }^{40}$ Rufaidah Al-Aslamiyah berbaiat kepada Nabi Muhammad setelah Nabi Muhammad hijrah ke Madinah. ${ }^{41}$ Saat itu, ia termasuk ke dalam golongan pertama yang masuk Islam. Ia mengambil peranan penting ketika Islam telah masuk ke kota Madinah. Peranan ia terbagi menjadi tiga, yakni peranan ia ketika sebelum peperangan Islam, peperangan Islam dan pasca peperangan Islam.

Sebelum peperangan Islam sekitar tahun 622 M, Rufaidah merubah metode pengobatan yang diajarkan oleh ayahnya dengan menyesuaikan ajaran Islam. Perubahan itu terkait dua hal. Pertama, terkait dengan tempat yang biasanya dijadikan oleh ayahnya sebagai tempat pengobatan. Ia membersihkan tempat itu menjadi nyaman, higienis, dan bersih. Tempat itu dulunya sangat kotor sehingga kenyamanan pasien tidak diperhatikan. Perubahan ini dilakukan atas dasar ajaran Rasulullah saw bahwa Islam merupakan agama yang mengedepankan kebersihan. Karena kebersihan sebagian dari iman. Kedua, menghilangkan jampi-jampi dan jimat untuk mengobati pasien. Menurut ajaran Islam itu bersifat syirik. Hal ini merupakan salah satu dosa besar. Ia menggantinya dengan doa-doa dan salawat yang diajarkan Rasulullah kepadanya. ${ }^{42}$

Atas perubahan-perubahan itu ia memiliki keutamaan pada zamannya. ${ }^{43}$ Ia melakukan pengobatan kepada setiap pasien-pasiennya selalu diiringi dengan berdakwah tentang keutamaan Islam. Ia meminta kepada pasiennya yang sedang terkena penyakit untuk meminta perlindungan Allah atas apa yang telah di deritanya.

Di tahun yang sama, ia juga telah mendirikan sekolah keperawatan pertama di dunia Islam meskipun lokasinya tidak dapat dilaporkan. ${ }^{44}$ Ia memimpin dan sekaligus mendidik para wanita muslim dibidang keperawatan atas izin dari rasulullah Saw. Maka dari itu, ia tidak hanya menghasilkan perawat tetapi juga mengikuti perintah Nabi Muhammad untuk memajukan pendidikan bagi para gadis dan wanita muslim. Ia dipercayai sebagai pendiri sekolah perawat pertama bagi wanita serta

${ }^{40}$ Syauqi, Rufaidah: Kisah Perawat Wanita Pertama Dalam Sejarah Islam. 13-14

${ }^{41}$ Salim, Nisa'a Haula Ar-Raasuul. 161

${ }^{42}$ Syauqi, Rufaidah: Kisah Perawat Wanita Pertama Dalam Sejarah Islam. 55

${ }^{43}$ Salim, Nisa'a Haula Ar-Raasuul. 161

${ }^{44}$ Carolyn Atkinson, "Islamic Values and Nursing Practice in Kuwait," Journal of Holistic Nursing American Holistic Nurses Association 33, no. 3 (2015). 196 
Rufaidah Al-Aslamiyah: Perawat Pertama di Dunia Islam (Abad 6-7 M.) |Abdul Hamid Saputra, dkk

mendorong wanita untuk menjadi pribadi yang terdidik. Ia telah berhasil mengenalkan kesempatan baru kepada kaum wanita untuk berkarir dalam menyediakan perawatan dan pelayanan bagi masyarakat. ${ }^{45}$ Maka, mereka terkenal dengan perawat pertama dalam periode Islam. Perawat wanita periode awal Islam ini dikenal sebagai "Al-Asiyah" dari kata kerja "aasa" yang berarti menyembuhkan luka. Terjemahan bahasa Arab perawat saat ini "mamarrida". 46

Selanjutnya, ketika peperangan Islam berlangsung sekitar tahun 623630 M. Rufaidah dan kelompok Al-Asiyah pergi ke Rasulullah. Mereka meminta izin pada beliau dengan mengatakan "Oh utusan Allah, kami ingin pergi ke keluar bersama kamu untuk perang dan merawat yang telah terluka dan menolong para muslim semampu kami." Rasulullah memberikan mereka izin untuk pergi. ${ }^{47}$ Ia berada di garis belakang untuk membantu tentara Islam yang terluka akibat perang. Ia juga membawakan makanan dan minuman untuk semua mujahid yang berperang bersama dengan para wanita yang lainnya. ${ }^{48}$ Dalam menunjang penanganan tentara yang terluka ia mendistribusikan makanan dan mendirikan rumah sakit lapangan untuk korban yang terluka. ${ }^{49}$

Rumah sakit lapangan Rufaidah adalah tenda palang merah pertama dalam sejarah manusia. Rumah sakit ini biasa digunakan ketika peperangan karena dapat berpindah-pindah. Rumah sakit ini juga dikelola oleh paramedis wanita yang terlatih. ${ }^{50}$ Rasulullah saw memerintahkan para sahabat yang terluka ketika peperangan untuk datang ke tenda Rufaidah. ${ }^{51}$ Rumah sakit ini kemudian dikenal dengan nama Khaimah Rufaidah (Tenda Rufaidah) yang kemudian menjadi latarbelakang penyebutan Rufaidah sebagai Mummaridah al-Islam al-Ula (Perawat Wanita Pertama dalam Sejarah Islam). ${ }^{52}$ Pada masa damai, rumah sakit ini berdiri disamping Masjid Nabawi untuk memberikan Islam." 75

45 Khasanah, "Rufaida Al-Asalmiya: Florence Nightingale Muslim Di Dunia

${ }^{46}$ Gail Tumulty, "Professional Development of Nursing in Saudi Arabia," Journal of Nusing School Scholarship 33, no. 3 (2001). 285

${ }^{47}$ Altaf, "Great Woman of Islam (Rufaidah Bint Sa'ad)."

${ }^{48}$ Talib Al-Hashmi, Tazqar a Sahabiah (Pakistan: Idara Al-Hassnat, 1981). 537

${ }^{49}$ Ruslan, "Rufaidah Al-Anshariyah Perintis Dunia Keperawatan Islam." 21

${ }^{50}$ Ruslan. 21

${ }^{51}$ Abu Ja'far Muhammad Bin Jariir Athabarii, Tarikh At-Thabari: Tarikh Rasul Walmuluk (Beirut: Darul Ma'arif Bimishra, 310AD). 586

${ }^{52}$ Syauqi, Rufaidah: Kisah Perawat Wanita Pertama Dalam Sejarah Islam. viii 
pelayanan kesehatan kepada masyarakat. Seiring berjalannya waktu rumah sakit ini tetap menjadi contoh luar biasa dari layanan medis Islam. ${ }^{53}$

Prof Omar Hasan Kasule dalam studinya menggambarkan Rufaidah sebagai perawat profesional pertama dalam sejarah Islam. Menurut Omar, ia digambarkan sebagai perawat teladan, baik, dan bersifat empati. "Rufaidah adalah seorang pemimpin, organisatoris, mampu memobilisasi dan memotivasi orang lain." 54

Kisah tentang Rufaidah ini ditulis oleh Al-Bukhari dalam kitabnya alAdab al-Mufrad, berikut terjemahannya:

Dari Mahmud bin Labid, ia berkata: "Ketika Sa'ad terluka parah dalam perang Khandaq, umat Islam membawanya kepada seorang perempuan yang bernama Rufaidah, yang memiliki kepandaian dalam mengobati orang-orang yang terluka. Kemudian saran itu dipenuhi, hingga apabila Rasulullah Saw. melewatinya pada sore hari, beliau bertanya kepada Sa'ad, "Bagaimana kabar mu sore ini?" dan jika beliau menjenguk di pagi hari, Rasulullah Saw. bertanya, "Bagaimana keadaanmu pagi ini?" Lalu Sa'ad memberikan jawaban kepada Rasulullah Saw." 55

Saad yang diceritakan dalam hadits diatas adalah Sa'ad bin Muadz. Ia adalah pemimpin penduduk suku Aus di madinah. Seorang sahabat Nabi yang selalu membela Nabi dalam menegakkan ajaran Islam bahkan sampai ia syahid karena luka yang diterimanya ketika perang Khandaq. Ketika itu Madinah telah di kepung oleh kaum musyrikin, kemudian direspon oleh kaum muslimin dengan cepat menggunakan baju perang. Sa'ad bin Muadz membawa pedang dan tombaknya sambil melantunkan syair: "Berhentilah sejenak dan nantikan berkecamuk perang. Betapa indahnya kematian ketika ajal datang menjelang."

Kisah di sekitar rumah sakit itu sendiri terjadi ketika Perang Ahzab atau Perang Khandaq (parit) tahun 627 M. Pada perang ini pasukan muslim membuat strategi dengan membuat galian parit di sekitar Madinah sehingga

${ }^{53}$ Salim, Nisa'a Haula Ar-Raasuul. 166

${ }_{55}^{54}$ Ruslan, "Rufaidah Al-Anshariyah Perintis Dunia Keperawatan Islam." 21

55 Muhammad ibn Ismail Al-Bukhari, Al-Adab Al-Mufrad (Al-Jubail: Daru AlShadiq, 1421). 408, lihat juga Muhammad Nasiruddin Al-Bani, Shahih Al-Adab Al-Mufrad Imam Al-Bukhari (Riyadh: Maktabah Ad-Dalil, n.d.). 434, lihat juga Maulana Khalid Khan Garhi, Manners in Islam: Al-Adan Al-Mufrad (Beirut: Dar Al-Kotob Al-Ilmiyah, 1971). 693-694

${ }^{56}$ Muhammad Khalid, Biografi 60 Sahabat Nabi (Jakarta: Umul Qura, 2013). 493 
pasukan musuh mendapati kesulitan dan terjebak di parit. Peristiwa ini terjadi pada bulan Syawal tahun lima Hijriah, antara pasukan muslim dengan pasukan gabungan Quraisy, Yahudi, dan Badui. Perang ini dilatarbelakangi oleh diusirnya kaum Yahudi dari bani Nadhir dan tinggal di Khaibar. Mereka mencoba memanfaatkan kesempatan untuk memprovokasi kaum Quraisy yang sudah jera untuk menghadapi kaum muslimin dan menawarkan upah kebun buah-buahan yang berlimpah kepada kabilah Gathafhan. Terbentuklah pasukan gabungan di bawah pimpinan Abu Sufyan dengan 10.000 pasukan. Mereka siap berangkat ke Madinah dan menyerang kaum muslimin. Mendengar berita tersebut, Rasulullah bermusyawarah dengan para sahabat. Salman Al Farisi menyarankan membuat parit, sebagaimana yang diterapkan oleh pasukan Persia pada masa-masa dahulu. Usulan itu pun diterima. Penggalian di sekeliling Madinah segera dilakukan dengan gigih selama enam hari. Parit telah selesai digali ketika pasukan musuh datang. Pasukan muslim yang berjumlah 3000 orang bersiap menghadapi musuh dari arah dalam. Pasukan gabungan datang dan mereka kebingungan untuk masuk Madinah. Mereka hanya bisa berputar-putar di sekeliling parit. Lalu, terjadilah panah memanah jarak jauh dan kibasan tombak atau pedang. Strategi ini sangat jitu sehingga tidak terjadi peperangan jarak dekat, akan tetapi tetap ada korban yang berjatuhan. ${ }^{57}$

Sa'ad bin Muadz terkena anak panah yang dilepaskan oleh kaum musyrik yang bernama Hiban bin al-'Araqah. ${ }^{58}$ Darah menyembur dari pembuluh darahnya. Nabi Muhammad saw sempat melakukan pertolongan pertama dengan pengobatan Kay. ${ }^{59}$ Pengobatan Kay adalah pengobatan yang dilakukan dengan cara menempelkan besi panas kepada luka. Pengobatan ini merupakan salah satu terapi pengobatan yang diperkenalkan Nabi Muhammad saw selain madu dan bekam. ${ }^{60}$ Nabi Muhammad Saw melakukan pengobatan al-Kay terhadap $\mathrm{Sa}$ 'ad hanya dengan tujuan 2010). 28

${ }^{57}$ Muhammad Saifudin, Atlas Dakwah Nabi Muhammad Saw (Bandung: Sygma,

${ }^{58}$ Abdurrahman bin Abdul Karim, Kitab Sejarah Terlengkap Para Sahabat Nabi, Tabi'in, Dan Tabi'it Tabi'in (Yogyakarta: Diva Press, 2014). 372

${ }^{59}$ Kang Afdol Kaf, "Luka Doa Dan Keputusan Hingga Azal Menjemput Sa'ad Bin Mu'adz (Bagian 3)," Hikmah 313, 2017, https://31.ayobai.org/2017/12/luka-doa-dankeputusan-hingga-azal.html.

${ }^{60}$ Syamsuri Ali, "Pengobatan Alternatif Dalam Perspektif Hukum Islam," Adalah 7, no. 4 (2015). 879, Lihat Juga Muhammad Idham Aditia Hasibuan, "Kontribusi Sains Dalam Menentukan Kualitas Hadis,” Edu Religia 1, no. 3 (2017). 229 
menghentikan darah yang mengalir dari luka Sa'ad karena khawatir Sa'ad kehabisan darah dan meninggal dunia. Ia segera dievakuasi dan dirawat darurat untuk menghentikan perdarahan yang ia alami. Kemudian Rasulullah Saw. bersabda kepada kaumnya: "Rawatlah Sa'ad bin Muadz di tenda milik Rufaidah agar aku dapat mengunjunginya dari dekat."61 Rufaidah merawatnya, secara hati-hati telah memindahkan anak panah dari lengan bawah dan telah mencapai homeostasis atau stabil. Rasulullah telah mengunjungi Sa'ad dalam tenda Rumah sakit beberapa hari. Sa'ad kemudian tewas sebulan setelah itu ${ }^{62}$ setelah pertempuran dengan Bani Quraidzah. ${ }^{63}$

Saad bin Muadz diminta oleh Rasulullah Saw untuk memutuskan hukuman apa yang tepat untuk menghukum bani Quraidzah. Ia dengan keadaan sakit di tenda Rufaidah di jemput oleh bani Aus atas perintah Rasulullah Saw. Mereka berangkat menuju benteng bani Quraidzah menggunakan seekor keledai yang telah diberi bantal dan kulit. Ia melihat rasulullah beserta kaum muslimin yang telah menunggu kedatangannya. Ia berpendapat bahwa hukuman yang tepat atas pengkhianatan mereka kepada Rasulullah Saw adalah eksekusi mati para pria, pembagian harta-harta mereka, dan penawanan wanita serta keluarga mereka. Rasulullah saw menyetujui pendapat Sa'ad bin Muadz. Bani Quraidzah yang berjumlah 600 sampai 700 orang dikumpulkan dan ditahan di Madinah. Mereka di eksekusi di pasar Madinah di sebuah parit yang di buat oleh Rasulullah Saw. Setelah itu Sa'ad bin Muadz kembali ke tenda Rufaidah lalu meninggal dunia. ${ }^{64}$ Bahkan ketika Sa'ad wafat dalam pertempuran itu Rufaidah yang merawatnya. ${ }^{65}$ Kemudian Rasulullah Saw. bersabda: "Arasy telah berguncang karena wafatnya Saad bin Muadz". ${ }^{66}$ Ilmu tafsir menyatakan

${ }^{61}$ Ibnu Hisyam, Sirah Nabawiyah (Jakarta: Akbar Media Eka Sarana, 2015). 572, Lihat juga Katsir, Ringkasan Bidayah Wa Nihayah: Sejarah Awal Mula Penciptaan, Kisah Para Nabi, Kisah Umat-Umat Terdahulu, Sejarah Nabi Saw Dan Khulafa' Rasyidun, Daulah Usmaniyah Dan Abasiyah, Hingga Peristiwa Tahun 768 H. 207

${ }^{62}$ Karim, Kitab Sejarah Terlengkap Para Sahabat Nabi, Tabi'in, Dan Tabi'it Tabi'in. 372-373

${ }^{63}$ Altaf, "Great Woman of Islam (Rufaidah Bint Sa'ad)."

${ }^{64}$ Al-Wakidi, Kitab Al-Maghazi. 565, Lihat juga Katsir, Ringkasan Bidayah Wa Nihayah: Sejarah Awal Mula Penciptaan, Kisah Para Nabi, Kisah Umat-Umat Terdahulu, Sejarah Nabi Saw Dan Khulafa' Rasyidun, Daulah Usmaniyah Dan Abasiyah, Hingga Peristiwa Tahun 768 H. 207-208

${ }^{65}$ Salim, Nisa'a Haula Ar-Raasuul. 161

${ }^{66}$ Al-Asfahani, Ma'rifah Ash-Shahabiyah. 3334 
Rufaidah Al-Aslamiyah: Perawat Pertama di Dunia Islam (Abad 6-7 M.) $\mid$ Abdul Hamid Saputra, dkk

bahwa maksud dari bergetarnya arasy adalah senang dengan kematian Sa'ad bin Muadz. ${ }^{67}$

Atas keterlibatannya dalam peperangan Islam, Rufaidah mendapat penghargaan khusus dari Rasulullah saw yaitu sebuah kalung indah. Beliau memakaikan langsung kalung itu dengan tangannya yang mulia ke leher Rufaidah. Hanya ia yang mendapatkan kalung itu dan ia begitu tersanjung dengan kalung itu sampai ia menyatakan: "demi Allah, kalung ini tidak akan terpisah dari jiwaku, dalam tidur dan dalam bangun $k u$, sampai aku menemui kematian”. Kemudian ia bahkan berwasiat jika ia meninggal dunia agar kalung itu dikuburkan bersama jasadnya. ${ }^{68}$

Penghargaan khusus itu diberikan karena ia telah mengorganisir para perawat dan memberikan peran wanita sebagai perawat yang berpartisipasi dalam perang suci. Karaha menjelaskan:

Setiap Mujahid (tentara) telah mengambil bagiannya; Rasulullah memberikan Koaiba (Rufaidah) bagiannya sama (adil) seperti pria karena ia telah bekerja selama perang dengan sepenuh hatinya dan merasakan lebih dari banyak pria. Koaiba (Rufaidah) sangat tercukupi dan berterimakasih banyak untuk bagiannya; ia telah percaya diri lagi, ia percaya ini dari Allah dan dalam bakatnya dan bakat-bakat dari wanita yang bekerja selama Jihad telah meningkat. ${ }^{69}$

Simbolisme dari pembagian yang sama dalam rampasan perang memberikan pesan bahwa perawat berguna dalam Islam dan mengangkat status wanita dalam peranan merawat. Al-Osimy menyatakan: "Status partisipasi wanita sebagai seorang perawat dalam perang menjadi dihormati besar dengan kesucian Rasulullah saw bahwa ia telah mempertimbangkan usaha mereka sebagai sebuah bentuk dari Jihad karena Allah. Ia telah memberi mereka hasil rampasan perang secara adil sebagaimana ia memberikan kepemilikan pria." Maka dari itu, kondisi ini telah memunculkan konsep jihad. Konsep ini menggambarkan layaknya sebuah "Pertempuran suci" untuk mendapatkan ridha Allah Swt. Jihad telah dihormati sebagai satu yang fundamental dalam Islam. ${ }^{70}$

${ }^{67}$ Karim, Kitab Sejarah Terlengkap Para Sahabat Nabi, Tabi'in, Dan Tabi'it Tabi'in. 377

\footnotetext{
${ }^{68}$ Syauqi, Rufaidah: Kisah Perawat Wanita Pertama Dalam Sejarah Islam. 7

${ }^{69}$ Lovering, “Arab Muslim Nurses’ Experiences of The Meaning of Caring.” 99

${ }^{70}$ Lovering. 11
} 
Konsep jihad telah menarik para wanita untuk ikut berperang, sejarah telah mencatat wanita-wanita yang bekerja bersama dengan Rufaidah dalam peperangan Islam. Mereka terdiri dari istri, bibi, dan para sahabat Nabi, diantaranya: Ummu Ammara, Aminah, Ummu Aiman, Safiyat, Ummu Sulaiman, dan Hindun. Semua wanita ini memberikan pelayanan yang tidak hanya terfokus kepada perawatan fisik saja lebih dari itu mereka juga memberikan dukungan sosial dan pemulihan pasca perang. ${ }^{71}$

Beberapa wanita yang secara aktif berpartisipasi dalam perang dapat ditemui pada zaman Rasulullah Saw. Pertama, seorang sahabat yang dijuluki Uтmи 'Umarah. Ia telah mendemonstrasikan keberanian dan keperkasaannya pada perang Uhud. Ia adalah Ummu Hakim. Isteri Ikrimah yang turut berperang melawan imperium Romawi. Kedua, Shafiyah binti Abd al-Mutallib. Saat umat Islam menderita kekalahan dalam perang muncullah kekacauan di dalam kamp Muslim. Shafiyah binti Abd alMutallib muncul meninggalkan Madinah menuju gelanggang perang dengan sebatang tombak, membangkitkan rasa malu para sahabat lelaki. Dengan marah, Shafiyah menegur, "mengapa kalian meninggalkan Nabi di belakang?" Ketiga, Asma binti Yazid. Ia merangsek ke depan dan membunuh sembilan pasukan musuh pada perang Uhud. Ketika itu ibunda Anas bin Malik, yaitu Ummu Sulaim, turut serta membantu suaminya berperang dengan sebilah golok. Keempat, Nenek Hasyraj ibn Ziad. Ia dan lima perempuan lain pergi ke medan perang Khaibar. Mereka melaporkan kepada Nabi, "Wahai Rasulullah! Meskipun pertolongan tergantung pada kehendak- Nya, kami akan tetap pergi ke medan perang, atau hanya sekedar memintal benang. Kebetulan kami memiliki obat-obatan bagi korban lukaluka. Kami siap pasangkan anak panah ini pada busur-busurnya. Bila perlu kami sediakan jelai air pada para serdadu". Kelima, Rubayyi binti Muawwidz ibn Afra. Ia adalah sahabat Rasulullah mengkarantina orang yang menderita sakit dan yang terluka serta menyuplai air pada para prajurit yang kehausan dalam perang. Bersama perempuan lainnya, ia juga mengangkut orang-orang yang terluka dan yang mati syahid dalam perang tersebut. Jika Nabi dan para sahabat mempertahankan Islam pada saat itu, wanita-wanita mulia itulah yang justru memanggul mesin senjata, dan fasilitas perang Islam." 75

71 Khasanah, "Rufaida Al-Asalmiya: Florence Nightingale Muslim Di Dunia 
lainnya. ${ }^{72}$ Keenam, Umayyah binti Qais al-Ghiffariah. Ia adalah muslimah yang pemberani turun ke medan perang untuk membantu dan merawat para sahabat yang terluka ketika ia masih usia belia. Ketujuh, Ummu Aiman. Ia adalah wanita yang bertugas menyiapkan minum bagi para pejuang yang kehausan dan mereka yang terluka dalam perang Uhud dan Khaibar. ${ }^{73}$

Keterlibatan para wanita-wanita ini di pimpin oleh Rufaidah. Dalam memimpin dan mengkoordinir mereka, Rufaidah telah menciptakan kode etik perawat di medan perang. Kode etik ini kemudian digunakan oleh keperawatan modern hingga saat ini. Ia telah menciptakan ini sekitar 1.400 tahun sebelum Florence Nightingale terkenal. ${ }^{74}$ Florence Nightingale adalah perawat pertama di dunia dalam versi masyarakat secara global. Ia terkenal atas keberhasilannya dalam memperkecil angka kematian tentara Inggris dalam Perang Crimean pada tahun 1864, sehingga menang dalam peperangan itu. Pemerintah Inggris memberikan ia kesempatan untuk mengembangkan perawat dan ia membuat institusi perawat di Inggris. Melalui pengalaman merawat selama perang ia membuat teori, kurikulum, dan kode etik perawat. Atas dukungan keluarga yang berasal dari keturunan bangsawan ia berjuang sebagai pelopor perawat dunia. ${ }^{75}$ Meski masyarakat global menganggap bahwa ia merupakan pelopor perawat pertama dunia, jika melihat periode waktu kita bisa menyimpulkan bahwa Rufaidah yang pertama melakukan praktik keperawatan modern. Terutama ketika Islam berkembang pesat di Madinah.

Keterlibatan Rufaidah tidak sebatas peperangan Islam berlangsung, ketika perang selesai atau masa damai ia tetap menjalankan peranannya dalam merawat orang yang sakit. ${ }^{76}$ Ia juga terlibat dalam aktifitas sosial di masyarakat. Ia memberikan perhatian kepada setiap muslim, miskin, anak yatim, atau penderita cacat mental. Ia merawat anak yatim dan memberikan bekal pendidikan. Ia selalu berusaha memberikan pelayanan terbaik bagi

\footnotetext{
${ }^{72}$ Munir, "Peran Aktif Perempuan Muslim.” 121

${ }^{73}$ Heri Ruslan, "Muslimah Pemberani Di Perang Khaibar," Republika, 2011.

${ }^{74}$ Rafat Jan, "Rufaida Al-Asalmiya,the First Muslim Nurse," Image: Journal of Nursing Scholarship 28, no. 3 (1996). 267

${ }^{75}$ Karen J. Egenes, History of Nursing (London: Jones and Barlett Publishers, n.d.). 5

${ }^{76}$ Salim, Nisa'a Haula Ar-Raasuul. 161
} 
Rufaidah Al-Aslamiyah: Perawat Pertama di Dunia Islam (Abad 6-7 M.) |Abdul Hamid Saputra, dkk

yang membutuhkan tanpa membedakan apakah kliennya kaya atau miskin. ${ }^{77}$ Ia digambarkan memiliki kepribadian yang luhur dan empati sehingga memberikan pelayanan keperawatan yang diberikan kepada pasiennya dengan baik pula. Sentuhan sisi kemanusiaan adalah hal yang penting bagi perawat, sehingga perkembangan sisi teknologi dan sisi kemanusiaan (human touch) mesti seimbang.

Ia mencurahkan pengetahuan, waktu dan pengalaman hidupnya untuk menyiapkan dan mendidik perawat dalam memenuhi kebutuhan masyarakat akan pelayanan dan perawatan kesehatan. Perannya dalam membangun dan meningkatkan keperawatan serta kesuksesan beliau dalam meletakkan aturan-aturan baru dan tradisi adalah sebagai dasar dalam memajukan keperawatan. $^{78}$

Atas dedikasi Rufaidah, Aba Firdaus mengutip sebuah puisi tentang ketokohan Rufaidah dari kitab al-Ilyazah al-Islamiyyah yang ditulis oleh Ahmad Muharram yang terjemahannya adalah sebagai berikut:

Wahai Rufaidah

Ajarkanlah Kasih sayang kepada manusia

Tambahkan ketinggian harkat kaummu

Ambillah orang yang terluka dan sayangi lah

Berkeliling lah di sekitarnya dari waktu ke waktu

Bila orang-orang tidur mendengkur

Maka janganlah engkau tidur

Demi mendengar rintihan orang yang sakit ${ }^{79}$

\section{Pengaruh Rufaidah Al-Aslamiyah bagi dunia keperawatan modern}

Praktik keperawatan yang dilakukan Rufaidah Al-Aslamiyah pada abad keenam telah mempengaruhi praktik keperawatan selanjutnya. Ia telah membuat karya-karya monumental pada zamannya yang kemudian digunakan oleh keperawatan modern. Karya-karya monumental ini meliputi rumah sakit lapangan, sekolah perawat, kode etik perawat, teori keperawatan, dan perawatan rohani Islam.

77 Asri Asmi, "Faktor-Faktor Yang Berhubungan Dengan Kepatuhan Perawat Dalam Penggunaan APD Di Ruang Rawat Inap Rs. Bhayangkara Makasar" (UIN Alaudin Makasar, 2017). 21 Islam." 75

78 Khasanah, "Rufaida Al-Asalmiya: Florence Nightingale Muslim Di Dunia

${ }^{79}$ Salim, Nisa'a Haula Ar-Raasuul. 166 
Sekitar tahun $627 \mathrm{M}$, ia telah mendirikan rumah sakit lapangan pertama dalam peradaban umat manusia yang dikenal dengan Khaimah Rufaidah. Rumah sakit ini pertama digunakan ketika perang Ahzab pada bulan Januari. Rumah sakit ini digunakan untuk menunjang para mujahid yang terluka dalam perang tersebut. ${ }^{80}$ Kegunaan rumah sakit ini tidak hanya sebatas perang saja. Ketika masa damai, rumah sakit lapangan ini digunakan untuk merawat masyarakat kota Madinah. Ia juga merawat para pendatang baru tunawisma yang pergi ke Madinah. ${ }^{81}$

Selanjutnya, dalam buku-buku sejarah rumah sakit lapangan baru dikenal di Eropa sekitar tahun 1792. Seorang dokter militer yang bernama Dominique Jean Lary telah membuat rumah sakit lapangan pertama di Perancis. Dalam bukunya yang berjudul Military Surgery menjelaskan bahwa ia telah menempatkan tenda-tenda darurat di dekat pertempuran. ${ }^{82}$ Kegunaan rumah sakit lapangan ini hampir sama persis dengan Khaimah Rufaidah. Meski pengaruhnya langsung atau tidak, yang pasti istilah rumah sakit lapangan ini dikenal lebih awal ketika zaman Rufaidah.

Selain rumah sakit lapangan, karya monumental lain dari Rufaidah Al-Aslamiyah yang berpengaruh terhadap keperawatan modern adalah sekolah perawat. Sekolah perawat Islam didirikan pada tahun $622 \mathrm{M}$, tidak lama setelah Rasulullah saw menetap di Madinah. Sekolah perawat ini didirikan atas izin Rasulullah saw yang tujuannya untuk mendorong wanita muda untuk menjadi pribadi yang terdidik dengan diperkenalkan peluang baru serta karier yang unik untuk wanita ${ }^{83}$ Tidak dapat dipastikan sekolah perawat ini lokasinya, akan tetapi yang pasti aktivitas keperawatan yang ia lakukan tidak terlepas dari Masjid.

Hampir sama dengan Rufaidah, sekitar tahun 1854 Florence Nightingale mendirikan sekolah perawat di Inggris. Sekolah perawat ini bernama Nightingale School of Nursing yang lokasi berada di rumah sakit St. Thomas di London. Sekolah perawat ini memiliki bentuk pendidikan yang berbeda pada umumnya, ia telah memunculkan metode baru dalam bentuk pendidikannya. Para pelajar perawat menggabungkan teori dengan

\footnotetext{
${ }^{80}$ Syauqi, Rufaidah: Kisah Perawat Wanita Pertama Dalam Sejarah Islam. viii

${ }^{81}$ Hossam, Encyclopedia of Islamic Medical Ethics Part III: Medical Care at and of Life (Amman: Fima, 2017). 42

82 Badiatul and Junaidi, 105 Tokoh Penemu Dan Perintis Dunia (Yogyakarta: Narasi, 2009). 80

${ }^{83}$ Jan, "Rufaida Al-Asalmiya,the First Muslim Nurse.” 267
} 
pengalaman klinis di rumah sakit. ${ }^{84}$ Maka dari itu, secara tidak langsung sekolah perawat ini telah dipengaruhi sekolah perawat Islam yang didirikan Rufaidah. Bahkan, 1.232 tahun sebelum sekolah perawat ini didirikan.

Jika sekolah perawat di Inggris tidak dipengaruhi secara langsung, berbeda dengan sekolah perawat yang ada di Pakistan. Sekolah ini bernama The Aga Khan University School of Nursing. Sekolah ini berdiri sejak tahun 1983 di Karachi, Pakistan. Sekolah ini secara langsung terpengaruh oleh Rufaidah. Salah satu gedung di sekolah ini diberi nama Rufaidah untuk mengenang peranannya. Mereka meyakini bahwa secara fisik ia telah meninggal tetapi pelayanan simbolis, pengabdian, perhatian, dan komitmen ia terhadap praktik keperawatan akan hidup selamanya. Mereka menyadari bahwa perawat adalah karier yang mulia untuk wanita muslim sesuai dengan tradisi Islam. ia menjadi teladan untuk para pelajar disana. Bagi mereka ia adalah perawat pertama, pendidik perawat, pemimpin perawat, dan pendiri sekolah serta klinik keperawatan pertama yang menjadi panutan mereka. ${ }^{85}$

Selain telah mendirikan rumah sakit lapangan dan sekolah perawat, Rufaidah menciptakan kode etik keperawatan untuk mengkoordinir para perawat melakukan selama merawat di medan perang dan masa damai sekitar abad ketujuh. ${ }^{86}$ Kode etik keperawatan ini berkaitan tentang cara merawat pasien yang berlandaskan ajaran Islam. Kemudian kode etik keperawatan bermunculan setelahnya, sesuai kebutuhan zamannya.

Di Inggris sekitar abad 19 telah muncul kode etik perawat atas ikrar yang dilakukan oleh perawat pertama Eropa yaitu, Florence Nightingale. Kemudian dikembangkan menjai kode etik perawat secara Internasional pada 1 Juli 1899 oleh International Council of Nurses. Kode etik ini telah mengalami revisi sekitar tahun 1973. Selanjutnya, di Amerika juga mengadopsi kode etik dari Florence Nightingale di bawah naungan American Nurses Association (ANA) sekitar tahun 1951. Di Indonesia sendiri kode etik keperawatan di atur oleh Persatuan Perawat Nasional Indonesia pada tahun 1989 dan direvisi pada tahun $2000 .{ }^{87}$ Setidaknya kode etik ini berfungsi untuk menghindari ketegangan antar perawat, memperbaiki status kepribadian, dan menopang pertumbuhan serta perkembangan kehidupan.

\footnotetext{
${ }^{84}$ Egenes, History of Nursing. 5

${ }^{85}$ Jan, "Rufaida Al-Asalmiya,the First Muslim Nurse." 268

${ }^{86}$ Jan. 267

${ }^{87}$ Egenes, History of Nursing. 5
} 
Ada hal penting lain selain etika keperawatan yang mempengaruhi praktik keperawatan, yakni teori keperawatan. Hampir sama dengan etika keperawatan, teori keperawatan pun muncul dan berkembang sesuai jiwa zamannya. Sekitar abad ketujuh, Rufaidah Al-Aslamiyah telah menggagas teori keperawatan untuk pertama kalinya. Dasar teori keperawatan ini adalah pelayanan kesehatan dapat diberikan kepada siapa saja tanpa membedakan yang kaya dan yang miskin. Pelayanan kesehatan juga dapa berupa pencegahan penyakit atau preventive care serta penyuluhan kesehatan (Health Education). ${ }^{88}$ Teori keperawatan ini bahkan masih digunakan sampai hari ini. Teori ini secara tidak langsung telah mempengaruhi teori-teori keperawatan di generasi selanjutnya.

Sekitar 1.400 tahun setelah teori keperawatan ini, teori keperawatan modern mulai berkembang yang dipelopori oleh Florence Nightingale. Ia telah meletakkan dasar-dasar keperawatan modern dengan mengidentifikasi peran perawat dalam menemukan kebutuhan dasar manusia pada pasien serta pentingnya pengaruh lingkungan di dalam perawatan orang sakit. Teori ini kemudian dikenal dengan teori lingkungan.

Teori lingkungan ini kemudian dikembangkan oleh Martha E. Rogers menjadi teori manusia sekitar tahun 1970. Menurut ia, manusia merupakan satu kesatuan yang utuh yang memiliki sifat dan karakter yang berbeda-beda. Sehingga, dalam melakukan keperawatan selain melibatkan lingkungan juga perlu memperhatikan sifat dan karakter manusia yang lebih dinamis. Maka, teori ini dipengaruhi oleh teori lingkungan.

Hampir sama dengan teori manusia, teori Myra Levine dipublikasikan sekitar tahun 1973. Teori ini memandang manusia sebagai makhluk hidup terintegrasi dan beradaptasi terhadap lingkungan. Praktik keperawatan hanya melakukan aktivitas konservasi. Teori ini mencoba menggabungkan antara teori lingkungan dengan teori manusia. ${ }^{89}$

Teori keperawatan selanjutnya terkait tugas perawat. Teori ini dikembangkan oleh Virginia Henderson sekitar tahun 1960-an. Teori keperawatan menurutnya adalah model konsep aktivitas sehari-hari dengan memberikan gambaran tugas perawat untuk mengkaji individu baik yang sakit atau yang sehat dengan memberikan dukungan kepada kesehatan,

\footnotetext{
${ }^{88}$ Jan, "Rufaida Al-Asalmiya,the First Muslim Nurse." 268

${ }^{89}$ Abdul Aziz, Pengantar Konsep Dasar Keperawatan (Jakarta: Salemba Medika,
} 2007). 57 
Rufaidah Al-Aslamiyah: Perawat Pertama di Dunia Islam (Abad 6-7 M.) $\mid$ Abdul Hamid Saputra, dkk

penyembuhan, serta meninggal dengan damai. Teori ini lebih mengedepankan keperawatan terhadap aktivitas manusia bukan tentang sifat maupun karakter manusia. ${ }^{90}$

Masih banyak teori-teori yang berkembang setelah teori keperawatan Henderson. Setidaknya teori keperawatan yang ada menjelaskan tentang manusia sebagai pribadi yang utuh dan unik. Kemudian, dipengaruhi juga oleh lingkungan yang menjadi sumber awal masalah terkait kesehatannya sekaligus menjadi sumber pendukung bagi kesehatan individu. Pada intinya keperawatan merupakan sebuah komponen penting sebagai faktor penentu pulihnya atau meningkatnya keseimbangan kehidupan seseorang. Istilah teori keperawatan tidak dikenal sebelumnya, akan tetapi Rufaidah Al-Aslamiyah telah mempelopori jauh sebelum keperawatan modern hadir.

Selain merintis beberapa karya monumental di atas, ia juga telah mengembangkan pelayanan Rohani Islam dalam pendidikan keperawatan. Sebenarnya, pelayanan rohani sudah dikenal sebelum ia lahir. Pelayanan rohani ini sudah ada sejak zaman primitif sekitar 3.000 - 4.000 tahun yang lalu. Ia mengembangkan pelayanan rohani dengan praktik keperawatan yang ia miliki yang berlandaskan ajaran Islam. ${ }^{91}$

Bentuk pendidikan ini dirintis agar para perawat Islam dapat memberikan pelayanan terbaik bagi yang membutuhkan tanpa membedakan apakah klien itu kaya atau miskin. ${ }^{92}$ Dasar perawatan rohani Islami adalah proses pengobatan, pemeliharaan dan pengembangan rohani dari segala macam gangguan dan penyakit yang mengotori kesucian fitrah rohani agar selamat sejahtera dunia akhirat didasarkan kepada tuntutan Al-Qur'an, AsSunnah, dan hasil Ijtihad melalui métodologi penalaran: instinbathiy (édukatif), istiqra'iy (induktif/riset), iqtibasiy (meminjam teori) dan irfaniy (laduni/hundhuri). ${ }^{93}$

Ia menganggap bahwa penyakit dapat menyerang fisik dan rohani seseorang. Perawatan rohani itu sangat penting karena bisa membersihkan dari penyakit-penyakit yang di derita oleh rohani. Oleh karena itu, dalam keperawatan ini manusia sangat dianjurkan untuk menjaga hati, lisan, dan

${ }^{90}$ Aziz. 46

${ }^{91}$ Kristen and Nola, Spiritual Care in Nursing Practice (Philadelphia: Lippincot Williams \& Wilkins, 2004). 50

${ }^{92}$ Tuti Alawiyah, "Metode Pelayanan Bimbingan Rohani Islam Rumah Sakit Bagi PPL Mahasiswa Jurusan BKI (Bimbingan Konseling Islam)," Orasi 1, no. 2 (2016). 1

${ }^{93}$ Alawiyah. 2 
tingkah laku agar ia sehat secara holistic (menyeluruh) baik bio, psiko, sosio, spiritual. ${ }^{94}$ Perawatan Rohani Islam ini lebih menekankan kepada pasien atau seseorang agar lebih mendekatkan diri kepada Allah SWT. Jiwa menjadi tenang, tentram, dan tanpa beban. Jiwa yang membias akan mengakibatkan penyakit psikosomatik. Terdapat tuntunan doa dan zikir bagi pasien sebagai pemenuhan nutrisi ruhani.

Selanjutnya, sekitar tahun 1820 - 1910 pelayanan rohani mulai berkembang seiring dinyatakannya Florence Nightingale oleh masyarakat sebagai perintis keperawatan modern. Kemudian orang-orang Eropa lebih mengenal pelayanan rohani dengan spiritual care. Pelayanan rohani yang dilakukan oleh ia hampir sama dengan pelayanan rohani yang dilakukan oleh Rufaidah pada abad ketujuh. Ia juga menggabungkan praktik keperawatan modern dengan pelayanan rohani. Akan tetapi, pelayanan rohani yang ia lakukan berlandaskan ajaran agama Nasrani. ${ }^{95}$

Jika dicermati dari awal, pengaruh Rufaidah sangat berkaitan dengan praktik keperawatan Florence Nightingale pada abad 19. Meski kita tidak dapat memastikan pengaruhnya ini terjadi secara langsung atau tidak. Akan tetapi, hal ini menjadi salah satu dasar bahwa sumbangan Islam terhadap peradaban Eropa sangat besar. Kajian kali ini telah membuktikan bahwa telah terjadi transmisi dan transformasi peradaban Islam kepada peradaban Barat, salah satunya adalah praktik keperawatan Islam.

\section{Kesimpulan}

Praktik keperawatan Islam telah berkembang sekitar abad keenam. Praktik ini seiring dengan perkembangan Islam di kota Madinah. Ciri praktik kesehatan ini adalah menggabungkan praktik kesehatan bangsa Arab badui, peradaban kuno, dan kesehatan Nabi. Tidak banyak data terkait praktik kesehatan saat itu, selain praktik kesehatan yang dilakukan sahabiyah Nabi yang bernama Rufaidah. Praktik kesehatan yang ia lakukan lebih terfokus kepada praktik keperawatan Islam.

Ia telah mendedikasikan hidupnya untuk dunia keperawatan. Orangorang menganggap dia sebagai mukhadram, yakni seseorang yang hidup di zaman jahiliah dan di zaman Islam sekaligus. Terkait dunia keperawatan, ia telah mengembangkan ilmu keperawatan di dunia Islam. Langkah-langkah

\footnotetext{
${ }^{94}$ Alawiyah. 2

${ }^{95}$ Kristen and Nola, Spiritual Care in Nursing Practice. 47-48
} 
yang diambil untuk mengembangkan itu dipengaruhi oleh dua zaman. Ketika zaman jahiliah, aktif dalam memberikan perawatan kepada masyarakat Madinah. Saat itu, perannya sebagai asisten ayahnya yang merupakan pimpinan para tabib di kota Madinah. Kemudian, ketika zaman Islam di Madinah perananya terkait tiga hal yakni, sebelum peperangan Islam, saat peperangan Islam, dan pasca peperangan Islam. Karena banyaknya perang saat itu, keperawatan Islam mengalami perkembangan dan mendapat apresiasi dari kalangan muslim Madinah.

Sebelum peperangan Islam dimulai, ia telah mendirikan sekolah keperawatan di kota Madinah sekitar tahun $622 \mathrm{M}$. Hal ini merupakan langkah awal yang ia lakukan dalam bidang ilmu keperawatan di Dunia Islam. Ia telah melakukan cara agar pengetahuan tentang praktik kesehatan dari ayahnya bisa dia kembangkan dan membantu masyarakat Madinah yang mengalami masalah kesehatan. Dengan mendidik kaum wanita tentang keperawatan, ia telah mengikuti perintah Nabi untuk memunculkan peranan wanita di masyarakat.

Ketika peperangan Islam berlangsung sekitar tahun 623-630 M, ia dan sahabiyah yang lain ikut membantu para mujahid. Mereka melakukan perawatan kepada mujahid yang terluka, membawakan makanan dan minuman, serta membantu menyediakan peralatan perlengkapan perang. Atas perintah Rufaidah, mereka membuat rumah sakit lapangan yang saat itu terkenal dengan Khaimah Rufaidah. Rumah sakit lapangan ini digunakan untuk menunjang proses perawatan mujahid yang terluka. Selanjutnya, Rufaidah juga telah menciptakan kode etik keperawatan selama berperang untuk mengkoordinir para wanita yang lain.

Pasca peperangan atau masa damai, kisah tentang Khaimah Rufaidah masih berlanjut. Ia mendirikannya di depan masjid Nabi dalam melakukan pelayanan kesehatan dan mendedikasikan hidupnya dalam aktifitas sosial masyarakat Madinah. Selain melakukan pelayanan kesehatan, dia juga memperhatikan orang-orang miskin, anak yatim, dan penderita cacat maupun mental.

Langkah-langkah yang telah dilakukan olehnya dalam mengembangkan ilmu keperawatan di dunia Islam secara langsung maupun tidak langsung telah mempengaruhi ilmu keperawatan modern. Secara tidak langsung, ilmu keperawatan modern yang digagas oleh Florence Nightingale pada abad ke-19 telah dipengaruhi oleh praktik keperawatan Rufaidah. 
Langkah-langkah yang dilakukan pun hampir sama seperti: membangun sekolah perawat, ikut berperang, menciptakan kode etik keperawatan, dan menggagas teori keperawatan. Akan tetapi, esensi di dalamnya berbeda karena jiwa zamannya berbeda pula. Namun, langkah-langkah yang dilakukan oleh Florence Nightingale telah dilakukan oleh Rufaidah sekitar abad ketujuh. Selain itu, pendirian rumah sakit lapangan yang dilakukan oleh D. Jean Lary juga telah terpengaruh oleh khaimah Rufaidah. Hal ini berkaitan dengan kegunaan dari keduanya yang memiliki kesamaan. Akan tetapi, Rufaidah telah memperkenalkan sekitar tahun $623 \mathrm{M}$ dan Jean Lary baru mempublikasikan nya sekitar tahun $1792 \mathrm{M}$.

Pengaruh ilmu keperawatan di dunia Islam secara langsung terkait dua hal. Pertama, pengaruhnya telah mengembangkan perawatan rohani Islam. Perawatan rohani Islam dikembangkan atas dasar penyakit yang di derita oleh para pasien yang tidak hanya terbatas oleh fisik saja. Akan tetapi, rohani juga termasuk salah satu elemen penting dalam manusia yang perlu dirawat. Perawatan rohani Islam ini dikembangkan berdasarkan konsep ajaran Islam. Perawatan rohani Islam ini kemudian berkembang dan sampai saat ini menjadi dasar bimbingan konseling Islam di Indonesia. Kedua, pengaruhnya telah menginspirasi berdirinya sekolah-sekolah perawat Islam di dunia Timur. Salah satu gedung di The Aga Khan University School of Nurshing telah mengabadikan namanya. Hal ini dilakukan untuk mengenang dedikasinya terhadap praktik kesehatan dunia. Terutama untuk mahasiswa universitas itu, mereka menjadikan dia sebagai salah satu teladan bagi perawat masa kini. 
Rufaidah Al-Aslamiyah: Perawat Pertama di Dunia Islam (Abad 6-7 M.)|Abdul Hamid Saputra, dkk

\section{Reference}

Abdurahman, Dudung. Metode Penelitian Sejarah. Jakarta: Logos, 1999.

Al-Asfahani, Aba Naim. Ma'rifah Ash-Shahabiyah. Riyadh: Darul Wathan, 1419.

Al-Bani, Muhammad Nasiruddin. Shahih Al-Adab Al-Mufrad Imam AlBukhari. Riyadh: Maktabah Ad-Dalil, n.d.

Al-Bukhari, Muhammad ibn Ismail. Al-Adab Al-Mufrad. Al-Jubail: Daru AlShadiq, 1421.

Al-Hashmi, Talib. Tazqar a Sahabiah. Pakistan: Idara Al-Hassnat, 1981.

Al-Wakidi, Imam. Kitab Al-Maghazi. Alamul Kutub, 1404.

Alawiyah, Tuti. "Metode Pelayanan Bimbingan Rohani Islam Rumah Sakit Bagi PPL Mahasiswa Jurusan BKI (Bimbingan Konseling Islam)." Orasi 1, no. 2 (2016).

Ali, Syamsuri. "Pengobatan Alternatif Dalam Perspektif Hukum Islam." Adalah 7, no. 4 (2015).

Altaf, Mohammad. "Great Woman of Islam (Rufaidah Bint Sa'ad)." Heart Beat, no.

(2008).

http://tabbaheart.org/wpcontent/themes/panoramic/library/images/newsl etters/Issue 02.pdf.

Aminah, Hikmatul. "Sejarah Kedokteran Masa Kemunduran Dinasti Abbasiyah (447-656 H/ 1055-1258 M)." UIN Sunan Ampel Surabaya, 2016.

Asmi, Asri. "Faktor-Faktor Yang Berhubungan Dengan Kepatuhan Perawat Dalam Penggunaan APD Di Ruang Rawat Inap Rs. Bhayangkara Makasar." UIN Alaudin Makasar, 2017.

Athabarii, Abu Ja'far Muhammad Bin Jariir. Tarikh At-Thabari: Tarikh Rasul Walmuluk. Beirut: Darul Ma'arif Bimishra, 310AD.

Atkinson, Carolyn. "Islamic Values and Nursing Practice in Kuwait." Journal of Holistic Nursing American Holistic Nurses Association 33, no. 3 (2015).

Aziz, Abdul. Pengantar Konsep Dasar Keperawatan. Jakarta: Salemba Medika, 2007.

Badiatul, and Junaidi. 105 Tokoh Penemu Dan Perintis Dunia. Yogyakarta: Narasi, 2009.

Briliantono. Allah Sang Tabib: Kesaksian Seorang Dokter Ahli Bedah. Jakarta: AMP Press, 2010. 
Rufaidah Al-Aslamiyah: Perawat Pertama di Dunia Islam (Abad 6-7 M.) |Abdul

Hamid Saputra, dkk

Dahlan, Andi Aswin. "Profesi Perawat Dalam Perspektif Islam," 2014. id.scribd.com.

Egenes, Karen J. History of Nursing. London: Jones and Barlett Publishers, n.d.

Farida, Umma. 25 Perempuan Teladan(Para Istri, Putri, \& Sahabat Perempuan Nabi Saw.). Kudus: STAIN Kudus, 2012.

Garhi, Maulana Khalid Khan. Manners in Islam: Al-Adan Al-Mufrad. Beirut: Dar Al-Kotob Al-Ilmiyah, 1971.

Hasibuan, Muhammad Idham Aditia. "Kontribusi Sains Dalam Menentukan Kualitas Hadis.” Edu Religia 1, no. 3 (2017).

Hisyam, Ibnu. Sirah Nabawiyah. Jakarta: Akbar Media Eka Sarana, 2015.

Hossam. Encyclopedia of Islamic Medical Ethics Part III: Medical Care at and of Life. Amman: Fima, 2017.

Jan, Rafat. "Rufaida Al-Asalmiya,the First Muslim Nurse." Image: Journal of Nursing Scholarship 28, no. 3 (1996).

Kaf, Kang Afdol. "Luka Doa Dan Keputusan Hingga Azal Menjemput Sa'ad Bin Mu'adz (Bagian 3).” Hikmah 313, 2017. https://31.ayobai.org/2017/12/luka-doa-dan-keputusan-hinggaazal.html.

Karim, Abdurrahman bin Abdul. Kitab Sejarah Terlengkap Para Sahabat Nabi, Tabi 'in, Dan Tabi'it Tabi'in. Yogyakarta: Diva Press, 2014.

Katsir, Ibnu. Ringkasan Bidayah Wa Nihayah: Sejarah Awal Mula Penciptaan, Kisah Para Nabi, Kisah Umat-Umat Terdahulu, Sejarah Nabi Saw Dan Khulafa' Rasyidun, Daulah Usmaniyah Dan Abasiyah, Hingga Peristiwa Tahun $768 \mathrm{H}$. Edited by Dr. Ahmad Al-Khani. Riyadh: Arsyad Maghal, 1424.

Khairiah. "Faktor-Faktor Yang Berhubungan Dengan Kepatuhan Perawat Untuk Menggunakan Alat Pelindung Diri Di Rumah Sakit Islam Faisal Makassar." UIN Alauiddin Makassar, 2012.

Khalid, Muhammad. Biografi 60 Sahabat Nabi. Jakarta: Umul Qura, 2013.

Khasanah, Uswatun. "Rufaida Al-Asalmiya: Florence Nightingale Muslim Di Dunia Islam.” Mutiara Medika 6, no. 1 (2006).

King, Charles R. "The Historiography Of Medical History: From Great Men To Archaelogy." Buletin of The New York Academy of Medice 67, no. 5 (1991).

Kristen, and Nola. Spiritual Care in Nursing Practice. Philadelphia: 
Rufaidah Al-Aslamiyah: Perawat Pertama di Dunia Islam (Abad 6-7 M.) |Abdul Hamid Saputra, dkk

Lippincot Williams \& Wilkins, 2004.

Lovering, Sandra. "Arab Muslim Nurses' Experiences of The Meaning of Caring." The University of Sydney, 2018.

Lubis, Chairuddin P. "Sejarah Ilmu Kedokteran." Usu e-Repository, 2008.

Mark, Jackson. A Global Histoty of Medicine. New York: Oxford University Press, 2008.

Maryam. "Perkembangan Kedokteran Dalam Islam." Sulesana 6, no. 2 (2011).

Mendel, Yavor. Pengobatan Kuno. Cambridge: Cambridge Satnfords Books, 2019.

Munir, Taufik. "Peran Aktif Perempuan Muslim." Muwazah 6, no. 1 (2014).

Niswati, Tri. Perspektif Kesehatan Masyarakat Teori Dan Aplikasi.

Yogyakarta: Deepublish, 2012.

Ruslan, Heri. "Muslimah Pemberani Di Perang Khaibar." Republika, 2011.

- "Rufaidah Al-Anshariyah Perintis Dunia Keperawatan Islam." Tabloid Republika. Jakarta, 2010.

Saifudin, Muhammad. Atlas Dakwah Nabi Muhammad Saw. Bandung: Sygma, 2010.

Salim, Muhammad Ibrahim. Nisa'a Haula Ar-Raasuul. Sudan: Maktabah Ibnu Sina, 1990.

Syauqi, Ahmad. Rufaidah: Kisah Perawat Wanita Pertama Dalam Sejarah Islam. Yogyakarta: Navila, 2010.

Syauqi, Muhammad Iqbal. "Sisi Lain Thibbun Nabawi: Nabi Tidak Mengubah Tradisi Pengobatan Bangsa Arab.” Islami, n.d. islami.co.

Tumulty, Gail. "Professional Development of Nursing in Saudi Arabia." Journal of Nusing School Scholarship 33, no. 3 (2001).

Walliman, Nicholas. Research Methods: The Basics. New York: Routledge, 2011. 
Rufaidah Al-Aslamiyah: Perawat Pertama di Dunia Islam (Abad 6-7 M.) $\mid$ Abdul Hamid Saputra, dkk 